\title{
If We Build It, Will They Come? Adoption of Online Video-Based Distance Learning
}

\author{
Nitza Geri \\ The Department of Management and Economics, \\ The Open University of Israel, Raanana, Israel \\ nitzage@openu.ac.il
}

\begin{abstract}
Technologies that enable interactive video lectures are becoming ubiquitous and affordable. The learning experience that video lectures offer students resembles in-class learning more than other options of distance learning. This study examines the adoption of interactive online video-based distance learning in a blended learning environment, where the students choose their mode of learning. It analyzes the enrollment of interactive online video classes in two introductory courses at the Open University of Israel, during the first six semesters in which this option was offered. The results are based on about 19,000 actual decisions of students. Only $7 \%$ of these decisions were to take the interactive video-based study group. This exploratory study suggests that, while students prefer face-to-face learning, the availability of video lectures may help all the students enrolled in these courses improve their achievements. In order to investigate this assertion further, the study examined the effectiveness of online video-based distance learning by comparing the achievements of overseas students before and after the inception of the video lectures. Interestingly, the results indicate that so far, video lectures have not significantly improved the perseverance as well as the achievements of overseas students.
\end{abstract}

Keywords: online video lectures, diffusion of innovation, blended learning, effectiveness of instructional technologies, continued use of information systems, social aspects of online learning, attention economy.

\section{Introduction}

Video lectures as a means of distance learning, or as a supplement to traditional in-class learning, have been around for several decades. Nowadays, technologies that enable both instructors and students to use video lectures are ubiquitous and affordable (Copley, 2007). Therefore, in the coming years, the use of video lectures as a means for distance learning, as well as for supporting traditional in-class learning is expected to increase.

Material published as part of this publication, either on-line or in print, is copyrighted by the Informing Science Institute. Permission to make digital or paper copy of part or all of these works for personal or classroom use is granted without fee provided that the copies are not made or distributed for profit or commercial advantage AND that copies 1) bear this notice in full and 2) give the full citation on the first page. It is permissible to abstract these works so long as credit is given. To copy in all other cases or to republish or to post on a server or to redistribute to lists requires specific permission and payment of a fee. Contact Publisher@InformingScience.org to request redistribution permission.

Video lectures offer students a rich learning experience, which resembles traditional in-class learning. Particularly, video lectures may have a potential to increase both student retention and achievements in distance and blended learning environments. However, prior research indicates that due to the essential human need to socialize, most stu-

\section{Editor: Alex Koohang}

An earlier, shorter version of this paper was presented at the Chais conference 2011, in Raanana, Israel, and included in Y. Eshet-Alkalai, A. Caspi, S. Eden, N. Geri, \& Y. Yair (Eds.), Proceedings of the Chais conference on instructional technologies research 2011: Learning in the technological era. Raanana: The Open University of Israel. http://www.openu.ac.il/research center/chais2011/papers.html 
dents prefer traditional in-class studying, even when they are offered a rich e-learning environment that includes video lectures, exercises, and personal online tutoring (Guri-Rosenblit, 2005). Hence, it is important to study the adoption of online video-based distance learning.

Video lectures may help students who cannot attend class (Wieling \& Hofman, 2010), and there is a growing phenomenon of both traditional and distance learning academic institutes that provide their students with access via the internet to recorded lectures. Furthermore, current technologies enable affordable interactive video sessions. Interactivity, which was rarely offered to students in the past, may increase the effectiveness of these videos. A study by Zhang, Zhou, Briggs, and Nunamaker (2006) compared three e-learning environments and one traditional classroom setting, and their findings indicated that the effectiveness of video learning was contingent upon providing the students with interactive video sessions. Zhang et al. (2006) suggested that, since the achievements of students who used the e-learning environment that provided noninteractive video did not improve, it might be important to integrate interactive instructional video into e-learning systems. The need for some sort of active engagement of students in learning is stressed by Cherrett, Wills, Price, Maynard, and Dror (2009), who suggested that passive observation of video is not cognitively captivating and challenging; hence, it is less effective for learning.

Many e-learning studies examine various aspects of discussion boards, which are considered as one of the primary tools of e-learning (Harman \& Koohang, 2005), or investigate the use of various internet platforms for collaborative learning, such as blogs (Blau, Mor, \& Neuthal, 2009), and GoogleDocs (Caspi \& Blau, 2011; Rimor, Rosen, \& Naser, 2010). However, few studies deal with video use for learning. Whatley and Ahmad (2007) summarize various ways of using video for supporting teaching and learning and describe their own use of video for recording summary lectures to aid students in their revision of face-to-face lectures. Brecht and Ogilby (2008) investigated video lectures that are used to support a traditional classroom course, and their results indicate that these videos may have helped the students pass the course, since $24 \%$ of students without the videos failed the course, whereas the failure rate dropped to $6.8 \%$ for the group that had the videos available. Precel, Eshet-Alkalai, and Alberton (2008) analyzed a course that was intentionally designed for online learning, which also included some video lectures. Although the students' attitudes towards the online content, including the video lectures, were positive, Precel et al.'s (2008) findings suggest that students prefer a blended learning model to a fully online course.

Technology acceptance (Venkatesh, Morris, Davis, \& Davis, 2003) and the diffusion of innovation (Rogers, 2003) are two related issues that have been heavily studied and still are not fully understood. Specifically, there is a need for studies that examine the adoption rate of new technologies, since this aspect has been rarely studied (Geri \& Naor-Elaiza, 2008; Jeyaraj, Rottman, $\&$ Lacity, 2006). This exploratory study examines the adoption rate of online video-based distance learning in a blended learning environment, where the students may choose their mode of learning. It is based on data of about 19,000 actual enrollment decisions. Another aspect that distinguishes this research is that there is a wide consensus that the analyzed information technology (i.e., the video lectures), which was also used by students who have chosen the traditional classes, is perceived as very helpful and effective. Over the examined period, the adoption rate has grown steadily, but never exceeded $16 \%$. Yet, the video lectures were available to all the students enrolled in these courses and may have helped them improve their achievements. The study compared the achievements of overseas students before and after the inception of the video lectures, in order to investigate their effectiveness. The preliminary results indicate that, so far, video lectures have not significantly improved the perseverance and the achievements of overseas students. 


\section{Theoretical Context: Key Innovation Characteristics}

There is a large body of research concerning technology acceptance (Venkatesh et al., 2003) and the diffusion of innovation (Rogers, 2003). This research focuses on rate of adoption, which is an aspect of adoption that needs further studying (Jeyaraj et al., 2006). The theoretical basis for this research draws on Barnes and Huff (2003), who extended Rogers' work (2003), and suggested seven key innovation characteristics that were found useful in explaining innovation diffusion outcomes.

- Relative advantage over the practice the innovation supersedes.

- Compatibility with what people do.

- Complexity, defined as the perceived relative difficulty of understanding and using the innovation.

- Trialability, which is the ability to experiment with an innovation before making an adoption (or rejection) decision.

- Observability, defined as the degree to which the results of an innovation use are visible to others.

- Image, defined as the degree the adoption and use of the innovation is perceived to enhance one's image or status.

- Trust, defined as the extent to which the innovation adopter perceives the innovation provider to be trustworthy.

Barnes and Huff's (2003) research demonstrated the applicability of these characteristics by using it for analyzing the causes for different paces of penetration of wireless Internet, specifically, the success of the iMode platform, which was based on Wireless Application Protocol (WAP), in Japan, and WAP's slow adoption rate in other countries. These seven key innovation characteristics are examined in this study as factors that may affect the rate of adoption of interactive videobased lectures by students.

\section{Methodology}

This study analyzed student enrollment of interactive online video classes in two introductory courses at the Open University of Israel. The Open University is a distance-learning institute with about 43,000 undergraduate students and 3,500 graduate students. The Open University's credo is open admission and academic excellence. Every year, the university recruits 11,000-12,000 new students. However, many of them drop out at the beginning of their studies because they are unable to meet the academic requirements. Since 1976, when the first semester of studies began, the Open University has awarded over 30,000 undergraduate and graduate degrees. During the academic year 2009-2010, 2,779 Bachelor's degrees, and 514 Master's degrees were awarded ("President's report," 2010). The university offers its students the choice of a full distancelearning model or a blended learning model. Students who choose the blended model combine face-to-face meetings with online support through course websites, which supplement traditional means of distance education, such as books and study guides.

The courses that were chosen for this study are "introduction to microeconomics" (hereafter, micro) and "introduction to macroeconomics" (hereafter, macro). They are both offered at the department of management and economics, and, in accordance with the open admission and academic excellence policy of the Open University, there are no prerequisites to these undergraduate courses (anybody may enroll), so many students fail or drop out. Usually, students choose to first 
study micro, and in the following semester, they take the macro course. Some students study both courses during the same semester.

Interactive video lectures were introduced in both courses on semester 2009B. The analyzed data refers to the first six semesters in which this option was offered. In each of these semesters, there were between 500 to 2,500 students enrolled to each of the two courses. The enrollments in each one of the fall (semester A) and the spring (semester B) semesters were 2,000 to over 2,500 students, and 500-600 students in the summer (semester C) semester, for the micro course. Whereas in the macro course there were 1,400-2,200 students enrolled for each of the fall and spring semesters and 600-750 in the summer. Overall, the analyzed data included about 19,000 actual enrollment decisions.

Students who were enrolled in an interactive video group were entitled to participate in a live video session. They could watch the session anywhere via the internet on their personal computer screen, communicate (e.g., ask questions) in real time with the instructor mainly through chat or phone, and get their answers during the same video session. The students could also choose just to watch the recording, which was posted on the course website about a day after the session took place. The video recordings were available to all the students enrolled to the course, but those who were not enrolled in the interactive video group could not watch the live sessions. The proportion of students who participated in the interactive video sessions, out of those who were entitled to do so, varied and usually was around $30 \%$ in regular sessions during the semester. It should be noted that many of the Open University's students work, and one of their reasons for studying at the university is that they are not obliged to attend class meetings. Their only obligation to physical presence is when taking the course final exam at the end of the semester.

Over and above the relatively large data set, another major consideration influenced the choice of these two courses as the object of this study. These interactive video lectures were considered excellent, and their quality and usefulness were well known. Both the micro and macro video lectures were given by the same instructor during the period examined in this study. Therefore, it was expected that they would be adopted by many students.

Five of the above mentioned key innovation characteristics suggested by Barnes and Huff (2003), were expected to increase adoption of the interactive video-based lectures by the students, especially those who took the micro course and then had to decide on their macro course mode of learning, in the following semester:

- Complexity. The technology was simple, available, and easy-to-use.

- Trialability. All students who took the micro course before the macro were exposed to the videos before deciding on their mode of learning of the macro course. Continuing students who studied other courses (e.g., statistics or mathematics) before taking the micro course may had also been exposed to video lectures by other instructors.

- Observability. As with trialability, the videos were visible to the micro students and to continuing students. Furthermore, a study of general attitudes of students towards video lectures in ten courses that had a video option, which was conducted at the Open University during semester 2009C (Steimberg et al., 2010), indicated that 93.6\% of the students thought that watching the videos may improve their understanding of the learning materials.

- Image. Using the internet for learning may be considered as enhancing one's image or status. This aspect was not examined in this study, but it can be safely assumed that the use of the videos is not perceived as damaging one's image or status. 
- Trust. The innovation provider (be it the university, the course academic team, or the instructor who teaches the video-based class) was perceived by the students as trustworthy.

The other two characteristics, relative advantage, and compatibility, are not necessarily the same for all students. Some may prefer face-to-face class meetings while others may like the flexibility of the online videos or the ability to watch and re-watch the videos on their own pace.

In order to explore the effectiveness of online video-based distance learning, the study compared the persistence and achievements of overseas students before and after the inception of the video lectures. Overseas students were chosen, and not the overall population of the students in these two courses, because they were unable to attend traditional class meetings. The other students, who were enrolled to traditional classes may have watched the videos as well as attending faceto-face class meetings or may have chosen, post factum, to abandon their class and study just from the videos. Of course, there were students who did not watch the videos at all. Overseas students may have also chosen not to watch the videos.

\section{Results}

Table 1 presents the total rate of students who have chosen video-based distance learning in each of the two courses, as well as the adoption rate of new and continuing students. As shown on Table 1 and Figure 1, the adoption rate of the video-based macro course is higher than that of the micro course. It should be noted that the population of students who study during the summer is different than that of semesters A and B. The summer students are usually more motivated and more successful. Some of them take these courses as prerequisites to MBA studies.

\begin{tabular}{|c|c|c|c|c|c|c|}
\hline Semester & 2009B & $\begin{array}{l}\text { 2009C } \\
\text { Summer }\end{array}$ & 2010A & 2010B & $\begin{array}{l}\text { 2010C } \\
\text { Summer }\end{array}$ & 2011A \\
\hline \multicolumn{7}{|c|}{ Introduction to Microeconomics } \\
\hline $\begin{array}{l}\text { Total students } \\
\text { Micro }\end{array}$ & $2.2 \%$ & $6.4 \%$ & $4.0 \%$ & $4.7 \%$ & $15.5 \%$ & $5.6 \%$ \\
\hline $\begin{array}{l}\text { Continuing students } \\
\% \text { distance }\end{array}$ & $2.8 \%$ & $7.9 \%$ & $5.6 \%$ & $6.7 \%$ & $21.6 \%$ & $8.7 \%$ \\
\hline $\begin{array}{l}\text { New students } \\
\% \text { distance }\end{array}$ & $1.5 \%$ & $4.8 \%$ & $2.6 \%$ & $2.3 \%$ & $6.9 \%$ & $3.4 \%$ \\
\hline * Z score & 2.29 & 1.52 & 3.82 & 5.06 & 4.73 & 5.46 \\
\hline * Significance & $*$ & & * & * & $*$ & $*$ \\
\hline \multicolumn{7}{|c|}{ Introduction to Macroeconomics } \\
\hline $\begin{array}{l}\text { Total students } \\
\text { Macro } \\
\end{array}$ & $2.6 \%$ & $15.9 \%$ & $8.9 \%$ & $8.7 \%$ & $15.9 \%$ & $12.6 \%$ \\
\hline $\begin{array}{l}\text { Continuing students } \\
\% \text { distance }\end{array}$ & $2.8 \%$ & $17.6 \%$ & $9.6 \%$ & $8.8 \%$ & $16.1 \%$ & $13.4 \%$ \\
\hline $\begin{array}{l}\text { New students } \\
\% \text { distance }\end{array}$ & $0.8 \%$ & $2.8 \%$ & $2.3 \%$ & $7.7 \%$ & $12.5 \%$ & $6.0 \%$ \\
\hline$*$ Z score & 1.38 & 3.23 & 3.22 & 0.46 & 0.72 & 2.71 \\
\hline * Significance & & $*$ & $*$ & & & $*$ \\
\hline
\end{tabular}

* Significance of difference between new and continuing students $(\alpha=0.05)$. 
In all the semesters, continuing students in both courses had higher tendency to choose the video option. This difference was significant in all the micro courses, except for the 2009 summer, but the difference was partly significant for the macro courses. Since during the six semesters there were 5,464 enrollments of new students to the micro course, versus 742 to the macro course, it may be concluded that new students are less inclined to choose interactive video-based online learning. Another possible explanation is that new students may be less aware of the video option.

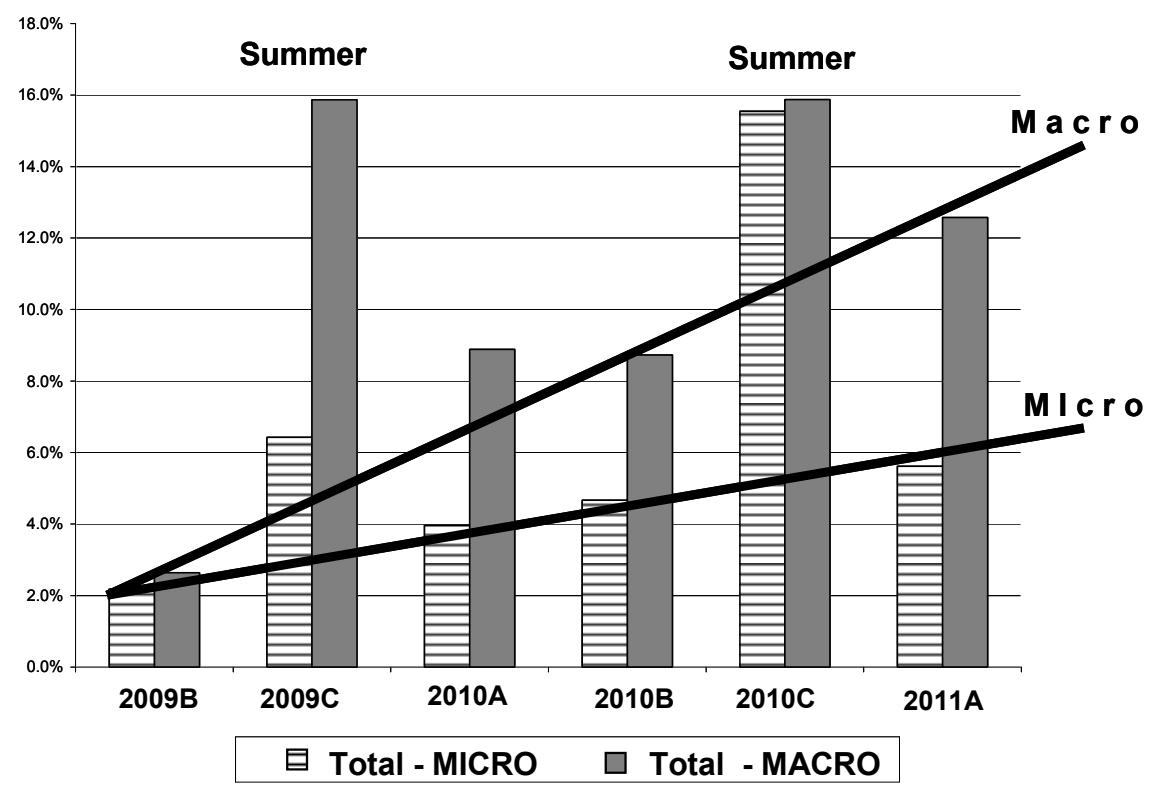

Figure 1: Total rate of adoption of video-based distance learning

Table 2 presents the achievements of overseas students during two semesters $(2008 \mathrm{~A}+\mathrm{B})$ before the inception of the video lectures and two semesters (2010 A+B) afterwards. The data of 2009 was not examined because it was the year of the change (there was no video on 2009A, but some students took their exams on 2009B instead of 2009A so they may have watched the videos). There is a dropout rate of nearly $30 \%$, but since many distance-learning students discontinue their studies due to various reasons (Levy, 2007; Simpson, 2003; Tinto, 1998; Woodley, 2004), the percentage of those who succeeded was calculated out of those who took the exam. Although the average exam grades, as well as the average final grades, in both courses were higher, none of the differences, but one, was statistically significant.

For the micro course, the average exam grade in $2008 \mathrm{~A}+\mathrm{B}$ was 79.5 , and it increased to 84.4 in $2010 \mathrm{~A}+\mathrm{B}$, but according to the $\mathrm{t}$-test, this increase was not significant $(\mathrm{t}(58)=-1.609, \mathrm{p}=.113$, equal variances assumed, Levene's test for equality of variances: $F=.018, p=.895)$. The effect size (Cohen's $\mathrm{d}=0.41)$ was medium. Although the t-test results for the final grade were significant $(t(58)=-2.116, p=.039$, Levene's test for equality of variances: $F=.018, p=.893)$, the effect size was medium $(\mathrm{d}=0.55)$.

As can be seen in Table 2, for the macro course the differences were even smaller and insignificant for both the exam grade $(\mathrm{t}(57)=-.562, \mathrm{p}=.576$, equal variances assumed, Levene's test for equality of variances: $\mathrm{F}=2.286, \mathrm{p}=.136, \mathrm{~d}=0.15)$, and the final grade $(\mathrm{t}(57)=-.953, \mathrm{p}=.344$, equal variances assumed, Levene's test for equality of variances: $\mathrm{F}=1.205, \mathrm{p}=.277, \mathrm{~d}=0.25$ ). 


\begin{tabular}{|lllll|}
\hline \multicolumn{5}{|l|}{ Table 2: Overseas students' achievements } \\
\hline Course & $\begin{array}{l}\text { Introduction to } \\
\text { Microeconomics }\end{array}$ & $\begin{array}{l}\text { Introduction to } \\
\text { Macroeconomics }\end{array}$ \\
\hline Semesters & $\begin{array}{l}\mathbf{2 0 0 8} \\
\mathbf{A}+\mathbf{B}\end{array}$ & $\begin{array}{l}\mathbf{2 0 1 0} \\
\mathbf{A}+\mathbf{B}\end{array}$ & $\begin{array}{l}\mathbf{2 0 0 8} \\
\mathbf{A}+\mathbf{B}\end{array}$ & $\begin{array}{l}\mathbf{2 0 1 0} \\
\mathbf{A}+\mathbf{B}\end{array}$ \\
\hline Total enrolled & 58 & 63 & 43 & 58 \\
\hline Took the exam & 35 & 40 & 32 & 38 \\
\hline \% Took the exam & $60.3 \%$ & $63.5 \%$ & $74.4 \%$ & $65.5 \%$ \\
\hline Succeeded & 28 & 32 & 26 & 33 \\
\hline $\begin{array}{l}\text { \% Succeeded (out of } \\
\text { those who took the }\end{array}$ & $80.0 \%$ & $80.0 \%$ & $81.3 \%$ & $86.8 \%$ \\
exam) & & & & \\
\hline Average exam grade* & 79.5 & 84.4 & 77.8 & 79.7 \\
SD exam grade & 11.8 & 11.8 & 11.9 & 13.8 \\
\hline Average final grade & 79.8 & 85.3 & 79.0 & 81.9 \\
SD final grade & 9.9 & 10.1 & 11.1 & 11.8 \\
\hline
\end{tabular}

* The average exam grade includes only the grades of the students who have passed the exam.

\section{Discussion}

The findings of this study suggest that the majority of students prefer attending traditional faceto-face class meetings. Nevertheless, the availability of videos may improve the achievements of all the students enrolled in a course. These results are in line with prior research (Guri-Rosenblit, 2005, 2009), according to which most students prefer the hybrid types of courses that combine new technologies, such as video, with conventional learning methods, and only those who cannot attend face-to-face class meetings choose distance-learning modes.

This study used the seven key innovation characteristics suggested by Barnes and Huff (2003) to examine qualitatively the likelihood of the adoption of online video lectures by students. While five characteristics (complexity, trialability, observability, image, and trust) are expected to increase video lectures adoption, it is unclear if this mode of learning is perceived by students as compatible to their way of learning and as having relative advantage over traditional methods. The relatively low adoption rate may be attributed to either lack of compatibility, or perceived ineffectiveness of online video lectures, or both. These questions should be examined in future studies. First, the effectiveness of video lectures and the factors affecting it should be better understood, and appropriate modifications should be applied to such systems. Then, the compatibility issue should be tackled. In that perspective, future studies should examine if resistance to change is a main cause of slow adoption.

The students' proclivity towards face-to-face classes may also be explained from an attention economy perspective (Davenport \& Beck, 2000, 2001; Geri \& Gefen, 2007; Simon, 1957, 1971). When students are attending class meetings, they focus for three hours on studying. Whereas, when studying at home or at work, their attention may be distracted by e-mails, phone calls, family members, co-workers who require their attention, and so forth.

The attention economy perspective may also explain the finding that providing overseas students with video lectures has not been found yet as significantly improving their perseverance and achievements. Although overseas students could attend the live video sessions, maybe most of them did not use this option, due to time zone differences and other reasons. As Cherrett et al. 
(2009) suggested, passive watching of video might not be enough to enhance learning. The actual mode of use of the video lectures by overseas students needs to be further studied, with larger samples.

The inclusion of video-based distance learning in these particular two courses is relatively new, and this study relates to the first two years of its use. It may be too early to draw conclusions at this stage. The results are based on about 19,000 actual decisions of students, and only $7 \%$ of these decisions were to take the interactive video-based study group. It should be noted that "introduction to microeconomics" and "introduction to macroeconomics" are introductory bachelor degree courses, so the findings may not be relevant for more advanced courses or degrees. More research is required in order to fully explore these issues.

Another direction for further studies is the continued use of online video lectures. The exploratory results presented in this study propose that students who may had prior positive experience with video lectures will be more inclined to continue using this mode of learning in other courses. However, students who had some sort of negative experience with video lectures may not be willing to enroll to other video-based study groups. They may also tell others and influence their tendency to try this medium.

\section{Conclusion}

The late Douglas Adams observed in a BBC Radio 4 series, entitled "The Hitchhiker's Guide to the Future" (Adams, 2001) that "relationship between different media tends to be complementary". Therefore, Adams explained, new media do not make older types disappear; "What usually happens is that older media have to shuffle about a bit to make space for the new one and its particular advantages". Adams illustrated that television did not kill radio or movies, but it did kill the cinema newsreel, because it delivered news immediately as it occurred, as opposed to the newsreel, which was updated on a weekly basis.

Likewise, interactive video lectures will not render traditional face-to-face class sessions obsolete. This study contributes to the diffusion of innovation research literature by measuring actual technology adoption rate data and by demonstrating that even an excellent technology, which its fine quality and advantages are highly visible to non-users, may not be widely adopted by the potential users.

\section{Acknowledgements}

The author is grateful to Galya Ofer and Adi Tamir of the department of Management and Economics, the Open University of Israel, for their cooperation and insightful comments.

\section{References}

Adams, D. (2001). The hitchhiker's guide to the future. A quote from BBC Radio 4 program. Retrieved May 21, 2011 from http://en.wikiquote.org/wiki/Douglas_Adams

Barnes, S. J., \& Huff S. L. (2003). Rising sun: iMode and the wireless internet. Communications of the $A C M, 46(11), 78-84$.

Blau, I., Mor, N., \& Neuthal, T. (2009). Open the windows of communication: Promoting interpersonal and group interactions using blogs in higher education. Interdisciplinary Journal of E-Learning and Learning Objects, 5, 233-246. Retrieved May 21, 2011 from http://ijklo.org/Volume5/IJELLOv5p233246Blau667.pdf

Brecht, H. D, \& Ogilby, S. M. (2008). Enabling a comprehensive teaching strategy: Video lectures. Journal of Information Technology Education, 7, 71-86. Retrieved November 8, 2010 from http://jite.org/documents/Vol7/JITEV7IIP071-086Brecht371.pdf 
Caspi, A., \& Blau, I. (2011). Collaboration and psychological ownership: How does the tension between the two influences perceived learning? Social Psychology of Education, 14(2), 283-298. Retrieved May 21, 2011 from http://www.openu.ac.il/Personal sites/avner-caspi/Download/Caspi Blau2011.pdf

Cherrett, T., Wills, G., Price, J., Maynard, S., \& Dror, I. E. (2009). Making training more cognitively effective: Making videos interactive. British Journal of Educational Technology, 40(6), 1124-1134. doi: 10.1111/j.1467-8535.2009.00985.x

Copley, J. (2007). Audio and video podcasts of lectures for campus-based students: Production and evaluation of student use. Innovations in Education and Teaching International, 44(4), 387-399. doi:10.1080/14703290701602805.

Davenport, T. H., \& Beck, J. C. (2000). Getting the attention you need. Harvard Business Review, 78(5), 118-126.

Davenport, T. H., \& Beck, J. C. (2001). The attention economy: Understanding the new currency of business. Boston, MA: Harvard Business School Press.

Geri, N., \& Gefen, D. (2007). Is there a value paradox of e-learning in MBA programs? Issues in Informing Science and Information Technology, 4(1), 163-174. Retrieved November 8, 2010 from http://proceedings.informingscience.org/InSITE2007/IISITv4p163-174Geri322.pdf

Geri, N., \& Naor-Elaiza, O. (2008). Beyond adoption: Barriers to an online assignment submission system continued use. Interdisciplinary Journal of E-Learning and Learning Objects, 4, 225-241. Retrieved November 8, 2010 from http://ijello.org/Volume4/IJELLOv4p225-241Ger476.pdf

Guri-Rosenblit, S. (2005). Eight paradoxes in the implementation process of e-learning in higher education. Higher Education Policy, 18(1), 5-29.

Guri-Rosenblit, S. (2009). Distance education in the digital age: Common misconceptions and challenging tasks, Journal of Distance Education, 23(2). Retrieved November 8, 2010 from http://www.jofde.ca/index.php/jde/article/view/627/886

Harman, K., \& Koohang, A. (2005). Discussion board: A learning object. Interdisciplinary Journal of Knowledge and Learning Objects, 1, 67-77. Retrieved November 8, 2010 from http://ijello.org/Volume1/v1p067-077Harman.pdf

Jeyaraj, A., Rottman, J. W., \& Lacity, M. C. (2006). A review of the predictors, linkages, and biases in IT innovation adoption research. Journal of Information Technology, 21(1), 1-23.

Levy, Y. (2007). Comparing dropouts and persistence in e-learning courses. Computers \& Education, 45(2), 185-204.

Precel, K., Eshet-Alkalai, Y., \& Alberton, Y. (2008). Students' attitudes toward a new pedagogical model for a fully online course. In Y. Eshet-Alkalai, A. Caspi, \& N. Geri (Eds.), Learning in the Technological Era: Proceedings of the Chais Conference on Instructional Technologies research (pp. 157H164H). Raanana, Israel: The Open University of Israel. [in Hebrew] Retrieved November 8, 2010 from http://telem-pub.openu.ac.il/users/chais/2009/evening/3 1.pdf http://telempub.openu.ac.il/users/chais/2008/noon/1 1.pdf

The President's report 2009-2010 . (2010). The Open University of Israel. Retrieved May 21, 2011 from http://www-e.openu.ac.il/presidents-office/report2010E/report2010E.html

Rimor, R., Rosen, Y., \& Naser, K. (2010). Complexity of social interactions in collaborative learning: The case of online database environment. Interdisciplinary Journal of E-Learning and Learning Objects, 6 , 355-365. Retrieved May 21, 2011 from http://www.ijello.org/Volume6/IJELLOv6p355365Rimor711.pdf

Rogers, E. M. (2003). Diffusion of innovation (5th ed.). New-York: The Free Press.

Simon, H. A. (1957). Models of man: Social and rational. New York: John Wiley and Sons.

Simon, H. A. (1971). Designing organizations for an information-rich world. In M. Greenberger (Ed.), Computers, communications and the public interest (pp.40-41). Baltimore, MD: Johns Hopkins Press. 
Simpson, O. (2003). Student retention in online, open and distance learning, London and Sterling, VA: Kogan Page.

Steimberg, Y., Guterman, E., Mermelstein, B., Brickner, R., Alberton, Y., \& Sagi, R. (2010). Students' perspective on teaching and learning with video technology at the Open University of Israel. In Y. Eshet-Alkalai, A. Caspi, S. Eden, N. Geri, \& Y. Yair (Eds.), Learning in the Technological Era: Proceedings of the Chais Conference on Instructional Technologies research (pp. 186H-194H). Raanana, Israel: The Open University of Israel. [in Hebrew] Retrieved November 8, 2010 from http://telem-pub.openu.ac.il/users/chais/2009/evening/3 1.pdf http://telempub.openu.ac.il/users/chais/2010/after_noon/4 1.pdf

Tinto, V. (1998). Colleges as communities: Taking research on student persistence seriously. The Review of Higher Education, 21(2), 167-177.

Venkatesh, V., Morris, G. M., Davis, G. B., \& Davis, F. D. (2003). User acceptance of information technology: Toward a unified view. MIS Quarterly, 27(3), 425-478.

Whatley, J., \& Ahmad, A. (2007). Using video to record summary lectures to aid students' revision. Interdisciplinary Journal of Knowledge and Learning Objects, 3, 185-196. Retrieved November 8, 2010 from http://ijklo.org/Volume3/IJKLOv3p185-196Whatley367.pdf

Wieling, M. B., \& Hofman, W. H. A. (2010). The impact of online video lecture recordings and automated feedback on student performance. Computers \& Education, 54(4), 992-998.

Woodley, A. (2004). Conceptualizing student dropout in part-time distance education: Pathologizing the normal? Open Learning, 19(1), 47-63.

Zhang, D., Zhou, L., Briggs, R. O., \& Nunamaker, J. F. Jr. (2006). Instructional video in e-learning: Assessing the impact of interactive video on learning effectiveness. Information \& Management, 43 (1), $15-27$.

\section{Biography}

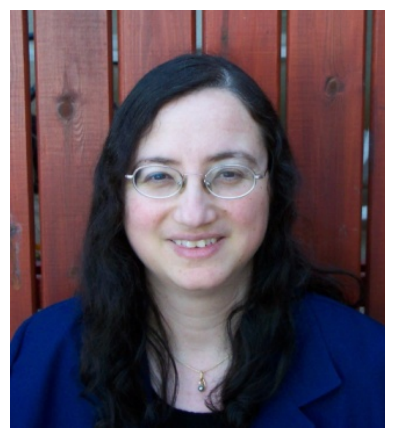

Nitza Geri is Head of the Department of Management and Economics, the Open University of Israel and a member of the Research Center for Innovation in Learning Technologies. She holds a B.A. in Accounting and Economics, an M.Sc. in Management Sciences, and a Ph.D. in Technology and Information Systems Management from Tel-Aviv University. Nitza is a CPA (Israel) and prior to her academic career she had over 12 years of business experience. Her research interests and publications focus on various aspects of the value of information, and information systems adoption and implementation, including strategic information systems, e-business, economics of information goods, attention economy, value creation and the Theory of Constraints, managerial aspects of e-learning systems adoption and use. Personal site: http://www.openu.ac.il/Personal_sites/nitza-geri.html 